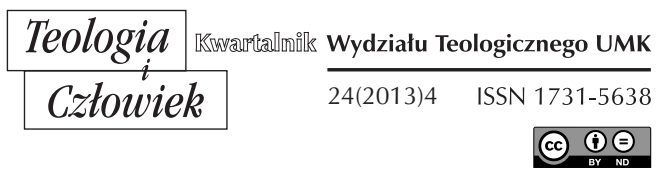

RAMIRO PELLITERO IGLESIAS*

PAMPELUNA (HISZPANIA)

\title{
PRAXIS EKLEZJALNA JAKO ŻYCIE WIARY
}

DOI: http://dx.doi.org/10.12775/TiCz.2013.046

\section{WIARA I ŻYCIE WIARY. NIEKTÓRE Z KORZENI OBECNEGO KRYZYSU}

1. List Porta fidei, napisany z racji trwającego obecnie Roku Wiary przedstawia horyzont życia wiary: przeżywać, poznać i przekazywać wiarę. Wszyscy chrześcijanie są wezwani, zwłaszcza teraz, do odkrycia na nowo wiary we wszystkich jej wymiarach, aby być świadkami Chrystusa. Jeśli nawet wyrażenie „życie wiary” pojawia się wprost jedynie jeden raz, jako istotowe odniesienie do treści doktrynalnej wiary wyrażonych w Katechizmie Kościoła Katolickiego, w liście Porta fidei termin „życie” pojawia się ponad 40 razy i wystarczyłoby uważne studium kontekstów i znaczeń tego pojęcia, aby przekonać się, że chodzi o szeroką wizję wiary, która wzywa nas, chrześcijan, i nas wprowadza, już w tym ziemskim życiu, do życia w komunii z Trójcą, co sprawia, że staje się ono już teraz początkiem życia wiecznego.

* Ramiro Pellitero Iglesias - profesor teologii pastoralnej, kapłan prałatury Opus Dei. Jest członkiem wielu stowarzyszeń międzynarodowych, międzywyznaniowych z zakresu teologii pastoralnej. Wykłada w USA, Kanadzie, Portugalii, Meksyku, Austrii. 
W zachodniej kulturze życie było intelektualnie podkreślane przez ruch romantyczny. Romantyczni teologowie katoliccy, głównie skupieni wokół szkoły z Tubingi, postawili fundament pod istotowe i egzystencje rozumienie wiary, które później tak mocno podkreślał Sobór Watykański II, mówiąc o wymiarze eklezjalnym, nad którym się dziś zatrzymujemy $\mathrm{w}$ naszej refleksji.

Brama wiary, mówi list Benedykta XVI „wprowadza do życia w komunii z Bogiem i pozwala na wejście do Jego Kościoła" (nr 1). To właśnie najpierw czyniąc się życiem, wiara znajduje swój oddźwięk w rodzinach, społeczeństwie i w kulturach. Niemniej jednak, jak również zauważa niemiecki Papież, dziś nie można już mówić tylko o konsekwencjach społecznych, kulturalnych i politycznych wiary, uważając ją za oczywistą:

Być może położono zbytnie zaufanie w struktury i pogramy kościelne, w rozdział władz i funkcji, ale: co się by stało, gdyby sól zwietrzała? [...] Nasza wiara ma fundament, ale trzeba, by ta wiara stała się życiem w każdym z nas. Dlatego trzeba podjąć wielki wysiłek, który sprawi, że każdy chrześcijanin stanie się świadkiem, gotowym zawsze i wszystkim do zdania sprawy z nadziei, która go ożywia [...]. Pokażcie waszym entuzjazmem, że wśród wielu sposobów na życie, które świat zdaje się nam proponować dzisiaj - wszystkie na tym samym poziomie - jedynym, w którym możemy odnaleźć sens życia i dlatego autentyczną i trwałą radość, to krocząc za Jezusem (Terreiro de Paço, 11 V 2010).

Zatem: praxis eklezjalna zakłada, że wiara staje się życiem, że wiara pokaże najpierw w każdym chrześcijaninie i jednocześnie w Kościele jako rodzinie Bożej, że może zaofiarować prawdziwy sens życia. To życie wiary (por. Guardini, $O \dot{z} y c i u$ wiary) jest jedynym pełnym życiem człowieka.

Stąd w tej epoce "głębokiego kryzysu wiary", wiara przeżywana osobiście i jako serce praxis eklezjalnej winna być odkryta na nowo, aby dać w ten sposób spójne świadectwo o Chrystusie. Pewnym przewodnikiem na drodze tego pogłębiania jest Sobór Watykański II, „wielka łaska, z której Kościół czerpie w XX wieku” (Jan Paweł II, NMI nr 57).

2. Wypada wskazać w refleksji nad korzeniami aktualnego kryzysu różne czynniki. Wskażę tutaj niektóre $\mathrm{z}$ nich, które wydają się bardziej istotne.

(1) W szczególny sposób trzeba podkreślić zmianę postrzegania tego, czym są dla człowieka świat, natura i kultura, a w tym kontekście 
także sam Bóg (por. R. Guardini, Zmierzch nowożytności). Ta zmiana odpowiada pojawieniu się nowożytności i reakcjom, które spowodowała $\mathrm{w}$ epoce postmodernizmu. Zatrzymamy się nad tym nieco dalej.

(2) Po drugie, sekularyzacja, albo ściślej mówiąc negatywne skutki sekularyzacji, wprowadzana w życie najpierw przez marksizm od połowy XX wieku i potem od maja 1968 roku i później przez relatywizm i konsumpcjonizm, wraz z pewnym tłem indywidualizmu, który odziedziczyliśmy po ostatnich wiekach.

(3) Po trzecie, myślę, że można mówić o braku reakcji dużej części teologii w ostatnich wiekach. Oczywiście istnieje inna część teologii, która wspaniale się rozwijała w ostatnim wieku, włączając do perspektyw katolickiej to, co najlepsze z takich nurtów, jak romantyzm, fenomenologia, personalizm etc. i zostawiając nam w spadku odnowioną kontemplację Boga i głębokie rozumienie Kościoła, oddzielonych od szkodliwości tak wielu błędnych idei, które nawet jeszcze dziś pojawiają się w środkach komunikacji i innych małych forach, choć bardzo aktywnych. Ale pomimo tego wielkiego rozwoju teologicznego trzeba jednak wskazać na deficyt dobrego pośrednictwa między światem akademickim i ulica, na której panuje głęboka nieznajomość wiary, rosnący „analfabetyzm religijny”. Mówiąc krótko, nie troszczyliśmy się w sposób wystarczający o formację pośredników (kaznodziei, katechetów, formatorów i wychowawców), pośredników między światem akademickim i kulturą popularną.

(4) Antyświadectwa i skandale prowokowane przez niektórych chrześcijan, zwłaszcza w ciągu ostatnich lat przez duchownych.

(5) Współczesne możliwości globalizacji i nowych technologii (które są bardzo dobre, gdy są używane dla dobra, ale również rozpowszechniają zło z większą łatwością).

3. Zatrzymajmy się przy pierwszym z tych czynników, nad nadejściem nowożytności $i$ reakcja postmodernizmu. Nasza sytuacja w tym względzie cechuje się pewnymi aspektami pozytywnymi, ze względu na reakcję na antyludzkie i antyreligijne ukierunkowanie nowożytności, ale nie zapominając o aspektach negatywnych, niektórych z nich bardziej lub mniej odziedziczonych po nowożytności. Co takiego stało się na przełomie II i III tysiąclecia, że stała się konieczna „Nowa Ewangelizacja?

- Po raz pierwszy (począwszy od czasów nowożytnych) człowiek żyje oddalony od natury: nawet, gdy pragnie wynieść ją nad inne, szuka drogi „racjonalnej” i nie „naturalnej”: przykładem jest agroturystyka „zorganizowana”, a sporty, które sprawiłyby, że 
lepiej poznałby człowiek naturę, szanując jej rozmiary, zostały „stechnicyzowane": wspinaczka górska, nurkowanie w morzach. Człowiek zagłębia się w przyrodę, ale zawsze "z góry”, panując nad nią. Traci prawdziwą kontemplację głębokich jej wymiarów. Można byłoby powiedzieć, że posługując się mediami - jako manipulator - aby ją poznać, w gruncie rzeczy ją obdziera, posuwając dalej "odczarowywanie” tak właściwe dla nowożytności i tracąc w ten sposób przesłanie "tajemnicy", którą skrywa natura, a co doprowadziło do Boga ludzi z wielu wcześniejszych pokoleń.

- Po raz pierwszy czlowiek panuje nie tylko nad elementami materialnymi, lecz nad samym życiem: najpierw życiem roślinnym - a to już od wielu wieków (uprawy selektywne etc.); potem zwierzęcym (selekcja gatunków dla ich większej produktywności); a ostatnio człowiek coraz bardziej żyje dystansując się mentalnie od samego człowieka: czasem dla dobrej sprawy, aby go leczyć; innym razem i coraz częściej dla uzyskania dóbr partykularnych, aby go dzielić wedle kryteriów, które obecnie dominują: poziom intelektualny, piękno fizyczne, siła fizyczna i panowanie nad sobą w sporcie, wybór płciowości etc. Życie ludzkie nie jest już darem, który podziwiam, ale stało się czymś, czym dysponuję, aby wybrać to, co chcę z nim zrobić: nauka i technika to drzwi, które otwierają prawdziwe „zdobycze” kulturalne. Tu rodzą się projekty tak problematyczne jak "trans-humanizm", który proponuje „zrobić” „człowieka ponadczłowieczego", pełnego protez, chipów i poszerzalnych twardych dysków.

- Po raz pierwszy człowiek nie żyje wpisany w kulture teocentryczna i w przypadku chrześcijanina „humanistyczną", której czułby się dłużnikiem, a która dostarcza mu kryteriów i miar ludzkiego życia oraz rzeczy znajdujących się wokół niego. Mamy dziś do czynienia z multikulturalizmem, który może nas ubogacić, pod warunkiem, że dotknie najgłębszych wartości każdej kultury, w przeciwnym razie staje się „drapieżnym multikulturalizmem”, który w imię globalizacji może wyrwać najbardziej ludzkie korzenie tradycji lokalnych (por. J. Bergoglio). Tu rodzi się niebezpieczeństwo, że stracimy motywację, aby przekazywać prawdę o naszych korzeniach i najgłębszych tradycjach pokoleniom, które po nas przychodzą. To, co istotne może pozostać w takim układzie, to chęć uczynienia z członków naszego społeczeństwa 
osób, które będą mogły utrzymać się w życiu dzięki środkom materialnym, kulturalnym i społecznych. O to właśnie prosi wielu rodziców, gdy przyprowadza swoje dzieci do szkoły czy wysyła na studia: aby odniosły „sukces” w życiu. Tak to rozumieją.

- Mając na uwadze to wszystko, widać, że relatywizm nie jest już zjawiskiem jedynie indywidualnym ani również właściwym podmiotom z kręgu elit. Stał się fenomenem masowym, niejako powietrzem kulturowym, którym oddychają dziś ludzie, nie będąc tego świadomym. Wpływa to także na chrześcijanina, który choć mniej lub bardziej przylgnął do Kościoła i jego nauczania, wychodząc z kościoła, grupy parafialnej czy rodzinnej, wchodzi w ten "dziki” multikulturalizm. Tym, co jest szkodliwe, nie jest sam „multikulturalizm”, lecz to, że chrześcijanin zachodni, przez kontakt z nowożytnym i postmodernistycznym procesem racjonalistycznym, powoli zostaje wypłukany z kontaktu z tajemnica, bardziej niż w innych kulturach: dotyczy to w mniejszym bowiem stopniu kultury arabskiej, hinduistycznej czy afrykańskiej. Nawet w Latynoameryce elity społeczne zostały dotknięty w ten sposób co kultura zachodnia, choć kultura ludowa nadal opiera się i dalej posiada wielki potencjał odnowy osób i rodzin (por. J. Bergoglio).

Do Ameryki Łacińskiej nie dotarła reforma luterańska, ledwo dotarło oświecenie i drapieżny racjonalizm wszedł praktycznie pod koniec XIX wieku, poprzez skrajny liberalizm, pozytywizm i masonerię, ale przypadł do gustu jedynie elitom. Szerokie rzesze ludności (miejscowej, Indianie i metysi) nadal trzymały się wiary i pobożności, ale brakowało formacji, dlatego też stracił poziom, który pobożność ta osiągnęła od XVI do XIX wieku, choć były szlachetne wyjątki.

Konsekwencją tego wszystkiego jest konieczność zmiany myślenia, gdyż nowa ewangelizacja nie powinna jedynie podejmować się większego „wyjaśniania” wiary chrześcijańskiej przy pomocy bardziej współczesnych słów, stosując media, którymi dziś dysponujemy: kino, muzykę, nowe technologie etc. Wszystko to należy zastosować i wykorzystać najlepiej jak się da, to znaczy, osiągając zbliżenie się poprzez te środki do osoby, która znajduje się blisko mnie. Ale nade wszystko - i jednocześnie musimy umieć z całą głębią i pomocą Ducha Świętego - łaski - pojąć realną sytuację, w której znajduje się każda osoba. A to po to, aby doprowadzić ją do: 
a) kontemplacji, podziwu i szacunku dla Natury, do podziwu nad światem i ziemią, które Bóg nam dał oraz podziwu nad życiem, na przykład odkrywając początek ludzkiego życia w rodzącym się embrionie, uczucia dziecka, które ma się dopiero narodzić (cierpi, śmieje się, jest poważny czy ruchliwy w łonie matki);

b) odkrycia własnej kultury (mam na myśli chrześcijańską kulturę zachodnią na poziomie ogólnym i kultury lokalne): wydaje mi się, że dużą rolę ma tu do odegrania sztuka nie tylko audiowizualna, lecz także ważne teksty wielkich klasyków, nie tylko z Grecji i Rzymu, również żydowskich, doktorów Kościoła, wielkich humanistów - jak Tomasz Morus, Luis Vices - konwertytów i chrześcijan żyjących konsekwentnie swoją wiarą w XIX i XX wieku. W ten sposób będziemy mogli pokazać, że substancjalnie i również kulturalnie oni są jak my, a my mamy łączność z ich niepokojami, bólami i radościami. Jest to dziś szczególnie ważne w kulturach lokalnych, ze względu na racje już wcześniej wskazane. Jednym słowem, musimy naprawdę uczynić historię magistra vitae, nauczycielką życia, nie narzucając jej w edukacji, lecz proponując i pomagając, aby nowe pokolenia ją odkrywały dzięki własnej pracy i wysiłkowi;

c) odczuwania i przeżywania "dumy" z tego, co wtasne, aby ubogacać wszystkim. Dzięki wspólnego wysiłkowi rodziców i szkoły nowe pokolenie powinno wejść na uniwersytet „dumne” z własnej kultury: z własnego kraju i jego wkładu kulturalnego dla ludzkości etc. Również „dumne” z własnej rodziny. Nie dlatego, że ich rodzice, dzieci czy bracia będą wpływowymi czy mądrymi, prestiżowymi osobami, czy pełnymi sukcesu przedsiębiorcami, albo politykami obecnymi w środkach przekazu etc., lecz dlatego, że dostrzegli w rodzinie gwaranta wartości, podtrzymującego ich przeżywanie i przekazywanie bez narzucania, szanując wolność dzieci, ponieważ sam Bóg jest pierwszym, który tę wolność szanuje, skoro uczynił nas wolnymi i nigdy nie łamie wolności żadnej osoby (nawet gdy szukając dobra pomyliliśmy się i zagrożeniu ulega nasza wieczna szczęśliwość czy dochodząc nawet do ludobójstwa).

4. Jako podsumowanie tej pierwszej części moglibyśmy powiedzieć, że wiara jest „projektem życiowym” (Jutta Burggraf). Wiara konfiguruje życie chrześcijanina, pokazując nam jako paradygmatyczne życie 
Abrahama i Dziewicy Maryi. Wiara ma moc przemieniania, pod warunkiem przyjęcia jej „ryzyka” (J.H. Newman), czym jest wychodzenie z własnych schematów i przekonań; i to nie jedynie na początku, ale zawsze. Wiara żywa i autentyczna w sposób konieczny przejawia się w dziełach; wiara jest osobista i intymna, ale pod warunkiem, że będzie przeżywana w rodzinie Bożej, która jest Kościót, jako zalążek ludzkości przemienionej, w całości, w rodzinę Bożą. Dlatego właśnie w tym projekcie życia, jakim jest wiara, centralne miejsce zajmuje świadectwo miłości, które jest najważniejszym przejawem wiary. Dziś papież Franciszek zaprasza nas właśnie do wyjścia z samego siebie, indywidualnie i zbiorowo, osobiście i instytucjonalnie, jako konsekwencję naszego życia wiary, również dla głoszenia wiary. Praxis eklezjalna, także z punktu widzenia instytucjonalnego, powinna pamiętać o tej konieczności kształtowania we wszystkich i każdym z osobna żywej wiary, aby bycie chrześcijaninem miało realną treść, w sposób konieczny związany z „byciem Kościołem”.

Praxis eklezjalna powinna dawać świadectwo - w swej organizacji, ale zwłaszcza postawie osób - jak bycie chrześcijaninem i bycie Kościołem nie jest polisą ubezpieczeniową, która mi gwarantuje „moje” zbawienie, lecz jest darem, który zostaje mi ofiarowany dla innych; w ten sposób osiągnę, kiedy Bóg zechce, zbawienie, ale „przyprowadzając z sobą wielu do nieba", odkrywając im Chrystusa i Jego Kościół, kładąc środki ludzkie i chrześcijańskie - jak czynili to święci - aby uzmysłowić im jak wspaniałą sprawą jest kroczenie za Chrystusem w Kościele. Jest to zadanie, które obejmuje całe życie: nauczyć się i innych uczestniczyć w misji Kościoła.

\section{NAWRÓCENIE I WYMIARY WIARY}

Chrześcijańskie świadectwo domaga się osobistego nawrócenia, które jest przede wszystkim nawróceniem religijnym i duchowym, ale właśnie z tego powodu posiada także wymiary intelektualne, moralne i kulturalne, pastoralne i edukacyjne (por. Lonergan) i wszystkie one powinny brać pod uwagę praxis eklezjalną jako taką. Dlatego dziś mówimy o „nawróceniu duszpasterskim”, aby wyrazić ponowne odkrycie naszej odpowiedzialności za budowanie Kościoła i uczestniczenie w Jego misji w świecie. Ale być może powinno się podkreślić zaangażowanie osobiste każdego chrześcijanina w nowej ewangelizacji, to znaczy w przekazywaniu czy komunikowaniu wiary innym ludziom. 
„Wiara bowiem rośnie, gdy przeżywana jest jako doświadczenie otrzymanej miłości i kiedy jest przekazywana jako doświadczenie łaski i radości. Sprawia ona, że życie wiernych wydaje owoce, ponieważ poszerza serca $w$ nadziei i pozwala na dawanie twórczego świadectwa: otwiera $\mathrm{w}$ istocie serca i umysły tych, którzy słuchają, na zaproszenie Pana, aby przylgnęli do Jego słowa, by stali się Jego uczniami" (Porta fidei, nr 7).

Przez zbyt długi czas, a zwłaszcza w ostatnim wieku, tak przedstawiano nawrócenie osobiste, że wydawało się, iż odnosi się jedynie do jednostki, a przecież nie istnieje coś takiego jak ,jednostka" wobec wiary. Przecież wiara czyni nas członkami Ciała Mistycznego, członkami jedni dla drugich w „my” Kościoła (por. Benedykt XVI). Eklezjologia może pomóc pokazać, że bycie chrześcijaninem oznacza bycie namaszczonym Duchem Świętym, aby kontynuować misję Chrystusa, licząc na działanie Chrystusa i Ducha osobiście i jako Kościół, rodzina Boża.

W konsekwencji praxis eklezjalna powinna pokazywać każdemu, począwszy od odpowiedzialnych za struktury duszpasterskie, że „zwłaszcza w tym Roku każdy wierzący powinien ponownie odkryć treść wiary wyznawanej, celebrowanej, przeżywanej i przemodlonej i zastanowić się nad samym aktem wiary" (Porta fidei, nr 9). Dlatego nasze działania formacyjne powinny prowadzić do „odżycia” wiary ze względu na nową ewangelizację. Powinno się to zacząć najpierw w każdym z nas, abyśmy się ponownie nawrócili i z poziomu naszego serca potrafili dać impuls tej „przeżywanej wierze”, która ma moc ożywić osoby, które nas otaczają i cały świat".

6. List Porta fidei podkreśla także te dwa aspekty wiary: relację między treściami wiary (wyrażonymi w Credo) $i$ aktem wiary. Wiara osobista zaczyna się z aktem wiary (decyzją i zgodą wyrażoną Bogu), który jest pobudzany przez łaskę Bożą. Nie wystarczy poznać treści wiary, lecz wymaga się „otwarcia serca” (por. Dz 16,14), aby zaakceptować to, co wiara proponuje. Trzeba pamiętać, że dokonuje się to nieustannie na drodze życia chrześcijanina, a nie jedynie na początku. Wszyscy możemy i powinniśmy otwierać się coraz głębiej na wiarę, wychodząc być może poza to, do czego się przyzwyczailiśmy w myśleniu i życiu wiarą.

7. Wiara ma konsekwencje dla inteligencji $i$ dla życia społecznego: prowadzi do „zrozumienia racji, przez której się wierzy” i „wymaga również odpowiedzialności społecznej za to, w co się wierze". Jak już zaznaczaliśmy, nie jest to coś czysto prywatnego i indywidualnego: „Samo wyznanie wiary jest aktem zarówno osobistym jak i wspólnotowym. Pierwszym podmiotem wiary jest faktycznie Kościól" (Porta fidei 
nr 10); gdyż chrześcijanin, który wierzy włącza się w Ciało lub rodzinę wierzących. Nie jest to przeszkodą, aby ten, kto szczerze szuka prawdy, choć nie ma jeszcze wiary chrześcijańskiej, posiadał już pewną „preambułę" wiary.

Relacja między wiarą a inteligencją chce uzmysłowić, że aby żyć wiara, trzeba pogłębiać znajomość „treści wiary”; jednocześnie jedynie życie wiara, żywa wiara czy żywe doświadczenie wiary pozwalają w całej pełni zrozumieć jej treści. W tej perspektywie Katechizm Kościoła Katolickiego jest „bardzo ważnym punktem odniesienia” dla odnowy życia kościelnego. Stąd każdy z nas powinien odnowić swoje zobowiązanie, aby „odkrywać i studiować” Katechizm Kościoła Katolickiego i przyczyniać się do jego stosowania w dziele formacji.

Może i powinno się to dokonywać przy zastosowaniu różnych metod. W każdym razie jest konieczne, aby „pośrednicy” potrafili personalizować treści wiary, aby oświetlać konkretne życie chrześcijan: ich prace, ich rodziny, relacje przyjaźni, działania społeczne i kulturalne. Wychodząc od życia naszych rodzin i wspólnot, na bazie praxis eklezjalnej jako przeżywanej wiary, studium Katechizmu Kościoła Katolickiego powinno prowadzić nas do stawiania sobie pytań co chce mi powiedzieć, co w sobie kryje, jak się „przekłada” i wciela w życie. Z tego pośredniczącego zadania wiary muszą wypływać później, już w każdym chrześcijaninie, wiele linii pracy własnej; to, co służy rodzinie, co jest pomocne dla tematów osobistych przemyśleń, odpowiedzi na wyzwania, które są aktualnie przeżywane; w przypadku szkół to, co wiara zakłada w każdym z przedmiotów, co wypadałoby dzielić z profesorami, co powinno się podejmować w rodzinach; a każdy z wiernych świeckich będzie mógł postawić sobie działania, aby dzielić się z innymi tym studium, mając na celu rozentuzjazmowanie ich życiem chrześcijańskim, rozumianym zawsze jako kult Boga i służba wszystkim, zdolne do przemiany społeczności.

Winno tak być również dlatego, że przeżywana wiara, skupiona na miłości caritas, wyraża jedność prawdy i miłości, a przy tym posiada istotne konotacje społeczne. Wiara (autentyczna) jest nierozdzielna od miłości, tak samo jak prawda jest nierozdzielna od miłości. Bez miłości wiara jest martwa (i przypomina wówczas typowy strach demonów, jak mówi apostoł Jakub: demony także wierzą i drżą). "A wiara, która pozwala nam rozpoznać Chrystusa jest tą samą Jego miłością, która pobudza, aby spieszyć Jemu z pomocą za każdym razem, kiedy czyni się naszym bliźnim na drodze życia" (Porta fidei, nr 14). 
8. Znaczacym dziełem "wiary przeżywanej" jest apostolat lub ewangelizacja, w której powinien uczestniczyć każdy chrześcijanin, na fundamencie osobistego świadectwa wiary, również poprzez trudności i krzyż (por. nr 15). Wiara przeżywana prowadzi do przekazywania wiary. Wiarę przekazuje się najpierw z miłością i radością, również przy osobistej spójności i potem poprzez słowa.

Na przykład, w szkołach o inspiracji chrześcijańskiej nie powinno się nauczać życia wiary jedynie na przedmiocie "religia", lecz na wszystkich przedmiotach, poprzez odpowiednią metodologię interdyscyplinarną (dialog „religii” $\mathrm{z}$ innymi przedmiotami, ponieważ w nim wyraża się dialog wiary i rozumu). Więcej jeszcze: to sam klimat szkoły wychowuje uczniów. A wyraża się to w radości, która przenika atmosferę szkoły. Trzeba to samo powiedzieć o parafiach lub grupach, ruchach kościelnych i innych rzeczywistościach eklezjalnych, każdy o własnym stylu. Wiara przeżywana ma już sama z siebie pewną skuteczność zbawczą. Być może nie chodzi tyle o czynienie „kampanii na rzecz radości”, ile o stałą i systematyczną, cichą pracę duszpasterską i wychowawczą (tak wiele doświadczenia $\mathrm{w}$ tym względzie ma ta polska ziemia!).

Tym samym prawem rządzi się rodzina: są rodziny $\mathrm{z}$ „dziećmi radosnymi" i to osiągają rodzice, którzy ufają Bogu i kochają swoje dzieci, poświęcając im czas i uwagę: temu, co opowiadają, ich zabawom, pytaniom, wprowadzając pokój, gdy ze sobą się sprzeczają... Jeśli dzieci nie są radosne, trzeba je zapytać, jaki jest tego powód: może to być zły stan zdrowia lub psychologiczna słabość..., ale często ta słabość jest rodziców. A wszystko to ma wiele wspólnego z wiarą i życiem wiary, jako przedmiotu praxis eklezjalnej i chrześcijańskiej.

\section{WYCHOWYWAĆ W "SYMFONII WIARY". DEKALOG EDUKACYJNY DLA NASZYCH CZASÓW}

Chciałbym zakończyć wystąpienie, podejmując temat wychowania do „wiary przeżywanej”. Jego centrum nie może być inne niż sam Chrystus, gdyż jak wielokrotnie $\mathrm{w}$ ostatnich latach rozważaliśmy, człowiek nie staje się chrześcijaninem poprzez decyzję etyczną czy wielką ideę, lecz poprzez spotkanie z wydarzeniem, z Osobą, która ofiaruje nowy horyzont życiu, a wraz z tym pewne decydujące ukierunkowanie (Deus Caritas Est, nr 1). 
Wiara przeżywana domaga się harmonii między różnymi wymiarami. Pomyślmy o fortepianie, na jego klawiszach powstają dźwięki mocne i delikatne. Dziś łatwo można zaobserwować, jak nauczanie religii, również $\mathrm{w}$ środowisku chrześcijańskim, polaryzuje się według prawa wahadła, za daleko wychylając się w stronę skrajności. $\mathrm{Z}$ jednej strony zagrożenie przed ustępliwością wobec relatywizmu i subiektywizmu, nihilizmu, laicyzmu i sekularyzmu, które jak się wydaje zaraziły wiele obszarów edukacyjnych. $Z$ drugiej strony pojawia się reakcja, wynikająca z nieznajomości soboru Watykańskiego II i być może w części będąca reakcją wahadłową na progresywną dechrystianizację, zmierza ku zamknięciu się $\mathrm{w}$ upadającym scholastycyzmie, związanym $\mathrm{z}$ pewnym woluntaryzmem i fideizmem, rygoryzmem i indywidualizmem.

Są to dwie skrajności, których należy unikać, ale przede wszystkim warto wiedzieć gdzie są mocne klawisze i te słabsze w naszym fortepianie, aby móc wygrywać na nich w sposób harmonijny naszą muzykę, która polega na chrześcijańskiej wizji osoby z wszelkimi jej konsekwencjami. Oczywiście wypada przypomnieć, że w ramach dobrej edukacji chrześcijańskiej jest miejsce na wiele prawowiernych i różnorakich wrażliwości.

Kto nie zna klawiszy, nie może grać na fortepianie ani współtworzyć symfonii. Wychowawcy, pośrednicy i formatorzy jesteśmy dziś zaangażowani w tę symfonię i powinniśmy dobrze poznać nasz instrument. Dziś symfonia wiary prosi, aby zwrócić uwagę na serię wymiarów, które najzwyczajniej są często nieobecne, czasami są, ale brakuje im równowagi i harmonii z innymi, stąd staje się czymś trudnym stworzyć razem takie akordy, który uprzyjemniają naukę muzyki. Każdy z nas może pomyśleć o swoich zadaniach edukacyjnych i duszpasterskich, zastanowić się, czy każdy klawisz jest na swoim miejscu, czy jest dobrze nastrojony, czy może razem z innymi tworzyć właściwy akord, aby nadawać muzyce życie i piękno. Wymienię teraz bardzo krótko swoisty „dekalog edukacyjny dla naszych czasów".

1. Kluczem wychowania chrześcijańskiego jest antropologia chrześcijańska (która jest ",antropologią transcendencji”, prowadzącą do życia i wychowywania w Kościele, rodzinie Bożej. To wymaga wyjaśnienia planu zbawczego Trójcy Świętej, ukazanego w Jezusie Chrystusie i realizowanego przez działanie Ducha Świętego. Wiara chrześcijańska „nie jest jakąś teorią, ale spotkaniem z konkretną Osobą, która żyje w Kościele. Po wyznaniu wiary następujące wyjaśnienie życia sakramentalnego, w którym Chrystus jest obecny, działa i nadal buduje swój Kościół. 
Bez liturgii i sakramentów, wyznanie wiary nie miałoby skuteczności, gdyż zabrakłoby łaski, która wspiera świadectwo chrześcijan. Podobnie, nauczanie Katechizmu na temat życia moralnego nabiera swego pełnego znaczenia, jeżeli umieszczane jest w kontekście wiary, liturgii i modlitwy" (Porta fidei, nr 11).

2. Potrzebujemy dziś zwłaszcza potraktować piękno jako "metodę" wychowania w wierze (przeciw ujęciom zbyt konceptualistycznym $\mathrm{z}$ ich akcentem na „prawdę" lub „dobro” rozumianych redukcyjnie w sensie moralizatorskim, z akcentem na powinność i obowiązek).

Zaczynając od piękna świata stworzonego i świata osobowego (którego kontemplację trzeba rozwijać, aby odkryć Boga miłość) oraz tak wielu przejawów kulturalnych, piękno życia chrześcijańskiego i wiary chrześcijańskiej może zostać ukazane za pomocą tekstów, obrazów, dzieł sztuki, narracji, kina, gier dla dzieci, muzyki.

3. Potrzebujemy także dobrej edukacji czy katechezy biblijnej. To znaczy więcej odniesienia do Biblii w perspektywie teologii biblijnej i nie tyle relacji zewnętrznych czy prostych zestawień, ile aby Biblia była naprawdę „duszą" wiary przeżywanej.

4. Wychowanie liturgiczne i sakramentalne. Zwłaszcza istotna jest edukacja liturgiczna z akcentem na "znaki święte”, ponieważ przez nie przychodzi „piękno, które zbawia” (Dostojewski). Oznacza to przedstawianie sakramentów jako aktualizacji miłości Boga względem nas: są to chwile i miejsce, w których działa Chrystus i Duch Święta jako „miłosne ręce” Ojca, aby przekazać nam życie i moc, ale także przez nas innym ludziom.

5. Życie moralne (przykazania Prawa Naturalnego udoskonalone przez Błogosławieństwa, które znajdują swoje ujście w cnotach chrześcijańskich, budowanych na dobrej formacji sumienia), powinno się przedstawiać nie jako zespół powinności, lecz jako powołanie $i$ odpowiedź na miłość Boga (dzieło Trójcy, zwłaszcza Ducha Świętego, w duszy), które winno przełożyć się na służbę innym w ich potrzebach materialnych i duchowych. Trzeba nauczyć przeżywania wiary z radością, stosując rozum, posiadając „racje” (również dla dzieci: proste argumenty, ale tchnące realizmem). W ramach formacji moralnej i zwłaszcza dla młodzieży wymaga się szczególnej uwagi na wychowywanie miłości ludzkiej, sensu ludzkiej seksualności, małżeństwa i rodziny.

6. Przeżywana wiara wymaga również, aby od dziecka przekazywać nauke społeczng Kościoła w sensie szerokim, to znaczy, społeczny wymiar moralności chrześcijańskiej lub po prostu dynamike społeczna życia 
chrześcijańskiego. Prowadzi to do wyjaśnienia i życia miłością jako tym, co najważniejsze w chrześcijaństwie (miłość do Boga i bliźniego), sprawiedliwość jako pierwsza miłość, miłosierdzie (uczynki względem ciała i ducha), konkretna troska o ubogich i najbardziej potrzebujących. Nie powinno stać się to jedynie nauczaniem teoretycznym „w klasie”, lecz winno nauczać się czyniąc to.

7. Modlitwa jako ufny dialog z Bogiem, który nas jednoczy z Jezusem, a dzięki działaniu Ducha Świętego prowadzi nas do Boga Ojca. Chodzi o autentyczną modlitwę, która prowadzi nas do wyjścia z samego siebie, aby troszczyć się o innych: o ich potrzeby materialnej (nauka społeczna) i duchowe (ewangelizacja i apostolat).

8. Dlatego dzieci powinny wyrobić w sobie zmysł i zwyczaj troski o innych, a zwłaszcza o to, aby ich najbliżsi z rodziny i przyjaciele byli blisko Boga (troska apostolska, ewangelizacyjna czy misyjna.

9. Świętość życia codziennego, ponieważ przeżywana wiara nie jest, dla większości chrześcijan, niczym innym jak szukaniem świętości w codziennym życia, uświęcając pracę, życie rodzinne, relacje społeczne i kulturalne (por. św. Josemaría Escrivá). W środowiskach wychowawczych chrześcijańskich oznacza to wymóg autentycznego świadectwa profesorów i nauczycieli, rodziców, kapłanów i wychowawców, który przekłada się na tysiące spraw małych i normalnych, które trzeba dobrze przygotować bazując na (nieprogramowalnej) miłości: powinniśmy w nich dostrzec, dzieciach, Jezusa, zwłaszcza w dzieciach ubogich i potrzebujących.

10. Zwłaszcza w tym Roku Wiary mogą zainicjować małe, ale konkretne projekty w szkołach, rodzinach, parafiach, rozwijając m.in. następujące punkty, zawsze gdy wychowawcy są gotowi do:

- pracy interdyscyplinarnej (w projektach o takim charakterze),

- współpracować i prosić o taką współpracę pasterzy Kościoła (którzy powinni coraz lepiej przygotowywać się do swej posługi z punktu widzenia wychowawczego),

- wspierać w konkretny sposób matki i ojców, całe rodziny,

- aspirować do wychowanie chrześcijańskiego o wysokiej jakości (jak mawiał św. Josemaría Escirvá „to, co najlepsze - dla Pana”), również dlatego, że rodziny tego potrzebują i o to nas proszą.

Tłum. z jęz. hiszp. - ks. Piotr Roszak 
Streszczenie. Niniejszy artykuł składa się z trzech części. W pierwszej przedstawiamy wiarę chrześcijańską jako „życie” w kontekście współczesnej teologii i kultury. „Kryzys wiary”, w którym żyjemy, ma różne historyczne korzenie, takie jak: nowoczesność, sekularyzacja, niewystarczający rozwój teologii, pewne antyświadectwa czy skandale itd. - które to pociągają za sobą przeszkody, by „żyć wiarą". W resultacie tego wszystkiego jest rzeczą konieczną zadać pytanie, jakie drogi powinny być obrane przez Nową Ewangelizację, jako współczesny wyraz kościelnej praxis, aby umocnić „życie wiary” wśród chrześcijan.

Druga część kładzie nacisk na chrześcijańskie świadectwo łacznie z osobistym i kościelnycm lub "pastoralnym” nawróceniem. Koniec pontyfikatu Benedykta XVI oraz początek pontyfikatu papieża Franciszka wskazywały na różne wymiary wiary, począwszy od uwrażliwienia na potrzebę i jakość nawrócenia (osobistego, kościelnego, społecznego, edukacyjnego, kulturowego itd.). Odnosiły się one także do „zawartości” wiary, jak to przedstawiono w Katechizmie Kościoła Katolickiego.

Podsumowując, trzecia część proponuje "dekalog edukacyjny" dla edukacji wiary dziś. "Symfonia wiary" powinna być zinterpretowana według wszystkich zasadniczych jej wymiarów, spośród których wielu dziś brakuje: chrześcijańska antropologia, a szczególnie edukacyjna ścieżka piękna; wymiar biblijny, liturgiczny i sakramentalny; edukacja moralna i wrażliwość społeczna, które muszą być dopełnione nauką modlitwy, świętości w życiu codziennym i apostolskiej lub misyjnej troski o wszystkich (począwszy od dzieciństwa). Edukacja wiary koniecznie musi być zadaniem interdyscyplinarnym, ze szczególnymi projektami na każdej z płaszczyzn działalności (rodzina, szkoła, parafia itd.).

Słowa kluczowe: wiara; życie chrześcijańskie; Kościół; duszpasterstwo; Nowa Ewangelizacja; edukacja katolicka.

Abstract. The ecclesial praxis as living faith. This conference has three parts. In the first part, we present the Christian faith as "life" in the contemporary theological and cultural context. The "crisis of faith" in which we are in has different historical roots -modernity, secularization, insufficient theological developments, certain counter-witness and scandals, etc. - which entail obstacles to that "living by faith". As a result of all this, it is necessary ask ourselves for the roads to be taken by the New Evangelization, as current expression of ecclesial praxis, to enforce the "life of faith" in Christians.

The second part emphasizes Christian witness along with personal and ecclesial or "pastoral" conversion. The end of the pontificate of Benedict XVI and the beginning of the new pontificate of Pope Francis have insisted on the various dimensions of faith, beginning by stressing the need and quality of conversion (personal, ecclesial, social, educational, cultural, etc.). They also referred to the "contents" of the faith, as outlined in the Catechism of the Catholic Church.

In conclusion, the third part proposes an "educational Decalogue" for the education of faith in our time. The "symphony of faith" has to be interpreted according to all its key dimensions, many of which are missing somehow today: Christian 
anthropology and especially the educational path of beauty; biblical, liturgical and sacramental dimensions; moral education and social sensibility, which must be completed with the education for prayer, holiness in ordinary life and apostolic or missionary concern in all (beginning from childhood); and finally education of faith must necessarily be an interdisciplinary task, with specific projects in each of the areas (family, school, parish, etc.).

Keywords: faith; Christian living; Church; pastoral; New Evangelization; Catholic education. 
